\title{
Sustainability and Digital as Challenges of Sociology
}

\author{
Sandro Serpa \\ Department of Sociology, \\ Faculty of Social and Human Sciences, \\ University of The Azores; \\ Interdisciplinary Centre of Social Sciences - CICS.UAc/CICS.NOVA.UAc; \\ Interdisciplinary Centre for Childhood and Adolescence - NICA -UAc, Portugal
}

\section{Carlos Miguel Ferreira}

\author{
ISCTE -University Institute of Lisbon, \\ Av. das Forças Armadas, Lisbon, Portugal; \\ Interdisciplinary Centre of Social Sciences -CICS; \\ Estoril Higher Institute for Tourism and Hotel Studies, Portugal
}

Doi: 10.36941/jesr-2020-0o23

\begin{abstract}
Bearing in mind that the prospect of the future is always a sensitive dimension to be addressed, this paper, based on bibliographic collection and analysis, as well as on the authors' academic experience, aims to add to the (re)thinking of some of the future challenges Sociology will face, in a sociologically informed society. It is concluded that sustainability and the digital are two of the crucial challenges for Sociology given the influence they exert, both in society and in the very way of doing sociology. Furthermore, to be successfully faced, there is the need for a concomitant articulation of a Sociology that amplifies its heuristic capacity to apprehend and respond to these challenges and the practice of fruitful interdisciplinarity, in which the different sciences accept and mobilize the contributions of other sciences. The existence of first-rate sciences compared to second-rate sciences has never been, is not and will never be the solution to (co)address these challenges.
\end{abstract}

Keywords: Sociology, sustainability, digital, ecosystems, environmental, interdisciplinarity

\section{Introduction}

The world is experiencing an intensification of interconnections. According to Magu (2015), "The world we live in is characterized by accelerating, intensifying and deepening social, economic, cultural, religious and recreational interconnections between one geographic and cultural area of one people to another. These interconnections have led to, and been characterized by, a respatialization and re-structuring of human relations occasioned and supported by rapid developments in technology, communication and language" (p. 642).

How can social sciences account for this? All social sciences acknowledge the existence of social change. Silva and Pinto (1986) claim that social sciences are "[...] aware that societies are installed in change, of the multiplicity of social times, attentive to the irreversibility and uniqueness of facts and 
the historical thickness of social structures" (p. 24).

Moreover, according to Nnebedum (2019), "The purpose of sociology is (and should be) to understand how human action and thinking can shape (and is being shaped by) these diverse subject matters" (p. 38). Specifically, in the emergence of sociology, philosophy of history, centered on the progressive liberation of man, the transformative theories of biology, centered on human and social evolution, and historical science were crucial dimensions that greatly influenced their founding proposals of sociology (Rocher, 1989). In summary, many of the first sociologists were, then, influenced by the idea of social evolution and progress (Adam, 2011; Aron, 1994; Cruz, 1989; Paiva, 2014).

Currently, among other factors, Sociology as a form of scientific knowledge (Ferreira \& Serpa, 2017), "thanks to the socialisation process that, through the learning of the culture of a given social environment, translated in ways of acting, thinking and feeling, allows the attainment of common expectations in social life, but always with some relative autonomy of the individual" (Serpa \& Ferreira, 2018, p. 841), implies having an empirical, analytical and systematic basis (Nnebedum, 2019). In a very relevant synthesis, Javeau (1998) proposes the features of Sociology as a science depicted in Table 1.

Table 1. Features of Sociology as a science

\begin{tabular}{|l|}
\hline Rejection of self-justifying universal explanation systems \\
\hline Does not consider progress without giving it a qualitative direction \\
\hline Affirms scientific paradigmatic plurability \\
\hline Primacy of deduction over induction without banning the latter \\
\hline Aims at setting up systems of comprehensive explanations of the real \\
\hline Does not consider as possible a predictability of the social future in a prophetic sense \\
\hline
\end{tabular}

Source: Javeau, 1998, pp. 64 and 65.

In this paper, we will focus our attention on the last feature: it is not possible to predict the social future in the prophetic sense. This goes against Sallum Jr.'s (2005) stance when the author affirms that "The processes of transformation of both the discipline and the social bases on which it rests are too complex in relation to our ability to identify the trends that should impose themselves in the future" (p. 19).

There are several factors potentially involved in social change, notably the demographic, geographic, technological, cultural, social and environmental (Guclu, 2019). "Social change is a social phenomenon and a natural social process. Change is not only formed by the internal structure within a society, but is also formed by factors outside of it. This change can be sometimes be slowed down, hampered, perhaps even redirected some, but not stopped completely" (Guclu, 2019, p. 70).

However, prophecy differs from grounded prediction (Adam, 2011; Vásquez, 2020; Rocher, 1989). Prophetism can be considered as described in Table 2.

Table 2. Characteristics of Prophetism

\begin{tabular}{|l|}
\hline Critical view of present society \\
\hline Order of thought of a meta-scientific nature \\
\hline Inspiring of an orientation \\
\hline Provide security and certainty \\
\hline Being optimistic or pessimistic \\
\hline
\end{tabular}

Source: Rocher, 1989, pp. 226 - 227. 
For its part, the prediction of the future must be substantiated, given that "the future is described, analyzed and explained within the framework of sociological discourse" (Volkov, Khunagov, Kumykov, Krotov, \& Magomedov, 2016, p. 9597). Tutton (2017) maintains that "Discursive constructions of the future are not simply imaginative in the traditional sense but are thoroughly social practices. These practices are in turn implicated in forming certain materialities and with letting loose both intended and unintended consequences" (pp. 10-14).

The prediction has several functions: clarifying, planning, organizing and educating (Table 3 ).

Table 3. Basic functions of human and social welfare

\begin{tabular}{|l|l|}
\hline Clarifier & understand better \\
\hline Project & expand and stimulate the imagination \\
\hline Organizational & achieve synergy between actors and generate development at all levels \\
\hline Educational & learn continuously and become aware of our active role in the present as builders of the future \\
\hline
\end{tabular}

Source: Vásquez, 2002, p. 252.

How can we understand and view the study of the social, in which "objective relations, for which representative cognitive constructions are sought, are intertwined in a network of particularly tight interconnections and interactions, and it is much more difficult to find isolable relations" (Castro, 1986, p. 300), in the context described above? As the prospect of the future is always a sensitive dimension to be addressed, this paper, based on bibliographic collection and collection, and also in the authors' academic experience, aims to add to the (re)thinking of some of the future challenges Sociology will face, in a sociologically informed society. For this purpose, a bibliographic search was carried out in the Scilit and B-ON databases, using the words "Sociology", "science", "future" and "sustainability" in the title and the abstract.

\section{Sociological Challenges}

In addition to the difficulty inherent in studying a future that, by definition, has not yet happened, with all the high degree of uncertainty it places on making predictions, "investigators affect the reality they study and that all research makes a difference in the world then, according to the Heisenberg principle, futurity is inescapably endemic to the scientific methodology" (Adam, 2011, p. 594). This can lead, for example, and according to Costa (1992), to self-fulfilling prophecy or selfdenying prophecy.

\subsection{Sustainability}

Lidskog, Mol and Oosterveer (2015) advocate that "Globalisation is perceived through changing social practices, institutional developments and social controversies in different and sometimes unexpected and unwanted ways in distinct geographies, sectors and social fields. [...] Globalisation has also affected the sociological study of interactions between society and the environment" (p. 340).

With the processes of globalisation, an idea of responding to globalised and interdependent needs has begun to emerge. Thus, sustainability as economics, ecology and social equity - "human welfare that takes into consideration inter- as well as intra-generational equity, and which does not exceed the limits of natural resource bases" (Passerini, 1998, cit. in Serpa \& Sá, 2019, p. 102) - has become an essential concept.

However, it is often insufficiently valued that sustainability is an extremely complex concept, and also a socio-historical one, which materialises (or not) in specific social contexts and situations of the human-natural relationship (Long, Clark, Shriver, \& Clausen, 2016; Lockie, 2016; Van Koppen, 2017; Lidskog et al., 2015) (Figure 1). 


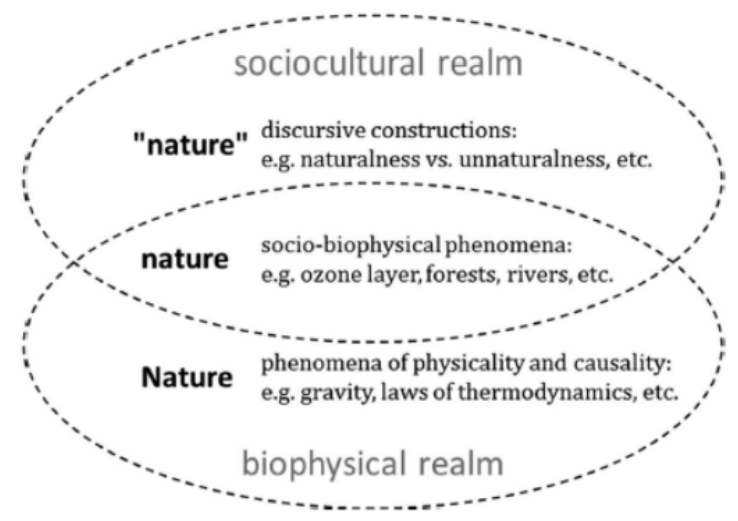

Figure 1. The interpenetrating sociocultural and biophysical realms that make up a causally dynamic ecological whole

Source: Van Koppen, 2017, p. 176.

Within this context, Lockie (2016) indicates two challenges for Sociology:

"First, by necessity, we must treat ecosystem processes, non-human species and machines as objects of sociological inquiry and theory building alongside people and institutions. We cannot treat the nonhuman either as self-evident or as the exclusive domain of the natural sciences [...]. Second, we must come to grips with the future orientation of sustainability and the need to apprehend social and ecological relations that have not yet been realized" (pp. 2 and 3).

The situation of the global environmental crises in promoting sustainable development that respects the future of the new generations implies that Sociology itself becomes global, respecting the set of dimensions put forth in Table 4.

Table 4. A global environmental sociology

\begin{tabular}{|l|}
\hline Dimensions: \\
\hline $\begin{array}{l}\text { Analyses local and place-based environmental issues while maintaining an understanding of their global } \\
\text { embeddedness and co-construction }\end{array}$ \\
\hline $\begin{array}{l}\text { Will understand global environmental issues by including place-based and contextual specificities, } \\
\text { practices and effects in the analysis }\end{array}$ \\
\hline $\begin{array}{l}\text { Explores how these national/regional approaches can fruitfully contribute to cross-boundary sharing of } \\
\text { and learning from findings and concepts }\end{array}$ \\
\hline $\begin{array}{l}\text { Has specific objects of thought and reflection (society - environment interactions), but the work of } \\
\text { investigating and explaining these is always related to general sociology }\end{array}$ \\
\hline $\begin{array}{l}\text { Disciplinary collaboration and the in-migration of disciplines should not result in the dissolution of the } \\
\text { sociological discipline, although it might become increasingly more difficult to distinguish sociology } \\
\text { from some of the other social sciences }\end{array}$ \\
\hline $\begin{array}{l}\text { Should and will have expanding global institutions but these expanding global research institutions } \\
\text { should not replace their national counterparts but instead complement them, and have to be recognised } \\
\text { by these national counterparts }\end{array}$ \\
\hline $\begin{array}{l}\text { Is not just a critical sociology of environmental problems, nor just a solution-oriented sociology of } \\
\text { environmental reform }\end{array}$ \\
\hline
\end{tabular}

Source: Lidskog et al., 2015. 
According to Haluza-DeLay and Davidson (2008), "The genius of sociology is its recognition of the dialectic of collective and individual processes that describe social systems, a methodology that can be applied to the complex interactions of societies and their environments. Sociology's relevance to environmental improvement also demands disciplinary self-reflexivity" (p. 634).

In this process, the interdisciplinary dialogue between various natural and social sciences is vital (Bhatasara, 2015; Jorgenson, 2016; Schroeder, 2010). Lidskog et al. (2015) argue that "natural sciences and their representations should not be taken as neutral inputs into environmental sociology; instead, they should be critically and sociologically investigated by placing them in their social context, and possibly opened up for discussion of what we really know about the state of the environment" (p. 347).

\subsection{Digital}

Digital technologies increasingly shape today's society and its cultures (Lupton, 2013, 2015; Nascimento, 2016). According to Lupton (2013), "People across the globe have becoming linked together by digital media and networks in unprecedented ways, allowing for the fast and efficient flow of information across these networks" (p. 2). All these shifts have an influence both on society and on the way sociology is done (Marres, 2017).

Concerning the influence of the digital dimension in society, several studies address Industry 4.o (which focuses mainly on the influence of the digital on production processes), as well as the concept of Society 5.o (focusing on the presence of the digital in all social sectors). Ferreira and Serpa (2018) sustain that, "opposing a deepening of the potential of the individual-technology relationship in fostering the improvement of the quality of life of all people through a super-intelligent society, Society 5.0 is an extremely recent concept as a guide for social development and that can have a profound impact on societies at all levels, such as in terms of the quality of life and sustainability" (p. 26).

One example of this is the presence of the digital influencing the educational process itself (Selwyn \& Facer, 2014) (Table 5).

Table 5. Areas of significant attention within an emerging 'sociology of education and technology'

\begin{tabular}{|l|}
\hline Digital technology and the reconfiguration of space, time and responsibility \\
\hline Digital technology and the (hyper) individualisation of education \\
\hline Digital technology and educational inequalities \\
\hline Digital technology and educational contexts \\
\hline
\end{tabular}

Source: Selwyn and Facer, 2014.

The digital is not neutral (Suchacka \& Horáková, 2019). It is yet another dimension to be considered in the processes of social inequalities (Nascimento, 2016), creating a new elite - Digital Suzerains with the ability to control and produce in digital technologies (DeSousa, McConatha, \& Lynch, 2011). Therefore, digital literacy - as a competence to mobilize both as a consumer and as a producer to enable good performance and functional participation in a digital context - is essential (Santos \& Serpa, 2017).

In an idea conveyed already of 2011, but that is still and always current, "the new technologies have altered social roles, statuses and norms in ways that are unexpected and unpredictable. Far from leading to the inevitable and onward march of an all-encompassing and overreaching capitalism, the new technologies have produced both systems and ideologies that undermine what would appear to be the taken-for-granted path as suggested by the social sciences" (DeSousa et al., 2011, p. 218).

The term digital sociology first emerged in the English-speaking academic literature in 2009 and already has a relevant background (Cf. Marres, 2017; Nascimento, 2016). The growing immersion of 
the digital has deep implications in the way of doing Sociology, some of them not yet fully considered and taken on by sociologists themselves (Table 6). As Lupton (2013) argues, "Digital sociology provides a means by which the impact, development and use of digital technologies and their incorporation into social worlds and concepts of selfhood may be investigated, analysed and understood" (p. 5).

Table 6. Four distinct aspects of digital Sociology

\begin{tabular}{|l|l|}
\hline $\begin{array}{l}\text { Professional digital } \\
\text { practice }\end{array}$ & $\begin{array}{l}\text { Using digital media tools as part of sociological practice: to build networks, construct an } \\
\text { online profile, publicise and share research and instruct students }\end{array}$ \\
\hline $\begin{array}{l}\text { Sociological analyses } \\
\text { of digital media use }\end{array}$ & $\begin{array}{l}\text { Researching the ways in which people's use of digital media technologies configures } \\
\text { their sense of selves, their embodiment and their social relations and the role of digital } \\
\text { media in the creation or reproduction of social institutions and social structures }\end{array}$ \\
\hline Digital data analysis & Using digital data for social research, either quantitative or qualitative \\
\hline $\begin{array}{l}\text { Critical digital } \\
\text { sociology }\end{array}$ & $\begin{array}{l}\text { Undertaking reflexive and critical analysis of digital media technologies informed by } \\
\text { social and cultural theory }\end{array}$ \\
\hline
\end{tabular}

Source: Lupton, 2013, p. 5.

This context poses sociologists profound and specific challenges (Carrozza, 2018, Lupton, 2013, 2015; Marres, 2017), which are summarized in Table 7. According to Lupton (2013),

"As an academic discipline, sociology has traditionally played an important role in identifying and commenting upon the role played by media and technologies in everyday life, social relations, social inequality, social institutions, selfhood and the body. In this spirit, and also as digital technologies increasingly become part of the academic world as it has in many other spheres, continuing critical and reflexive examination of these technologies and their implications for academic practice and selfhood should be an integral dimension of sociological research" (p. 13).

Table 7. Challenges for sociologists posed by the new digital media

\begin{tabular}{|l|l|}
\hline The digital data economy & Sociologists' position as empirical social research experts \\
\hline Digital data and Web 3.o & Sociologists' computational and data analysis expertise \\
\hline The politics of circulation & Sociologists' control over the products of their research \\
\hline MOOCS, open access publishing, citation indices & Sociologists' employment conditions \\
\hline Social and other digital media expertise & Sociologists' professional and public profiles \\
\hline
\end{tabular}

Source: Lupton, 2013, p. 12.

Considering that "Digital social research is not only a way of knowing society, as if from the outside, it is equally a participant in wider dynamics of mutual adjustment between digital settings, actions and content" (Marres, 2017, pos. 156), the study of digital mediation in the social, at various levels, can only be fully achieved through interdisciplinary research strategies (Witte, 2012; Lupton, 2013, 2015; Marres, 2017), acknowledging the "unstable identity of digital social research techniques" in a methodological uncanny (Marres, 2017). Moreover, following this author, "digital social research operates in a space between technology and methodology. We must design our research both with and against the digital: with and against the data formats, measures and features inscribed into the devices and infrastructures with which we conduct our enquiry" (Marres, 2017, pos. 97).

\section{Conclusion}

Sustainability and digital are two of the future challenges for Sociology. These challenges can only be 
met successfully if Sociology deepens its internal knowledge on these issues and, at the same time, there is a deepening of the interdisciplinary dialogue. In the intradisciplinary issue, Sociology is, admittedly, "a low-consensus discipline, where different schools of thought have distinct expectations about suitable scientific practices. Future research should focus on how the mechanisms manifest themselves within different paradigms and how they prohibit the exchange of ideas. Otherwise, Sociology might increasingly give way to an archipelago of sub-disciplines with their own domains of knowledge but a limited ability to produce new insights" (Schwemmer \& Wieczorek, 2019, p. 1). In terms of interdisciplinarity as the promotion and mobilisation of synergies from two or more different scientific disciplines (Serpa, Ferreira, \& Santos, 2017), this is a key process (Nnebedum, 2019; Serpa et al., 2017), but which faces specific difficulties, given that "The scientific method relies on the accumulation and integration of the findings of individual researchers into a cumulative body of knowledge. The construction of a common body is a gigantic task, given the diversity of disciplines, methods, interests and applications found in this research community" (Whitte, 2012, p. 85).

Interdisciplinarity, if properly put in practice, has high heuristic potential (Duschinsky, 2019; Lyle, 2016), but the following prevention is very pertinent: "Sociologists embarking on similar endeavours should ensure there is shared commitment towards a social issue to prevent the marginalization of sociological research" (Lyle, 2016, p. 1169).

It is concluded that sustainability and digital are two of the crucial challenges of Sociology and that, to be successfully addressed, a concomitant articulation will be needed to shape a Sociology that expands its heuristic capacity to grasp and respond to these challenges, as well as the practice of fruitful interdisciplinarity, in which the various sciences accept and mobilize the contributions of other sciences. The existence of first-rate sciences compared to second-rate sciences has never been, is not and will never be the solution to address these challenges.

\section{Acknowledgements}

University of The Azores, Interdisciplinary Centre of Social Sciences-CICS.UAc/CICS.NOVA. UAc, UID/SOC/o4647/2019, with the financial support of FCT/MEC through national funds and, when applicable, co-financing from FEDER under the PT202o Partnership Agreement.

\section{References}

Adam, B. (2011). Wendell Bell and the sociology of the future: Challenges past, present and future. Futures, 43(6), 590-595. doi: 10.1016/j.futures.2011.04.007.

Aron, R. (1994). As etapas do pensamento sociológico [The stages of sociological thinking]. Lisboa: Publicações Dom Quixote.

Bhatasara, S. (2015). Debating sociology and climate change. Journal of Integrative Environmental Sciences, 12(3), 217-233. doi: 10.1080/1943815x.2015.1108342.

Carrozza, C. (2018). Re-conceptualizing social research in the "digital era". Issues of scholarships, methods, and epistemologies. Análise Social, LIII(228), 652-671. doi: 10.31447/asooo32573.2018228.05.

Castro, A. (1986). A causalidade nas ciências sociais: Uma abordagem epistemológica [Causality in social sciences: An epistemological approach]. In A. S. Silva, \& J. M. Pinto (Orgs.), Metodologia das ciências sociais [Methodology of social sciences] (pp. 279-312). Porto: Edições Afrontamento.

Costa, A. F. (1992). Sociologia [Sociology]. Lisboa: Difusão Cultural.

Cruz, M. B. (1989). Teorias sociológicas. Os fundadores e os clássicos (Antologia de textos) (I Vol.). Émile Durkheim [Sociological theories. The founders and the classics (Anthology of texts) (I Vol.). Émile Durkheim]. Lisboa: Fundação Calouste Gulbenkian.

DeSousa, V., McConatha, D., \& Lynch, M. J. (2011). The nexus of digital technology, sociology and economics. The International Journal of Interdisciplinary Social Sciences, 5(10), 211-219.

Duschinsky, R. (2019). Attachment and the archive: Barriers and facilitators to the use of historical sociology as complementary developmental science. Science in Context, 32(3), 309-326. doi: 10.1017/so269889719000243.

Ferreira, C. M., \& Serpa, S. (2017). Challenges in the teaching of sociology in higher education. Contributions to a discussion. Societies, 7(4), 30, 1-11. 
Ferreira, C. M., \& Serpa, S. (2018). Society 5.o and social development: Contributions to a discussion. Management and Organizational Studies, 5(4), 26. doi: 10.5430/mos.v5n4p26.

Guclu, I. (2019). Social change and development: A critical comparison of classical with contemporary sociological theory. Studies in Asian Social Science, 6(2), 66-76. doi: 10.5430/sass.v6n2p66.

Haluza-DeLay, R., \& Davidson, D. J. (2008). The environment and a globalizing sociology. Canadian Journal of Sociology, 33(3), 631-656. doi: 10.29173/cjs4157.

Javeau, C. (1998). Lições de sociologia [Lessons of sociology]. Oeiras: Celta Editora.

Lidskog, R., Mol, A. P., \& Oosterveer, P. (2015). Towards a global environmental sociology? Legacies, trends and future directions. Current Sociology, 63(3), 339-368. doi: 10.1177/0011392114543537.

Lockie, S. (2016). Sustainability and the future of environmental sociology. Environmental Sociology, 2(1), 1-4. doi: 10.1080/23251042.2016.1142692.

Longo, S., Clark, B., Shriver, T., \& Clausen, R. (2016). Sustainability and environmental sociology: Putting the economy in its place and moving toward an integrative socio-ecology. Sustainability, 8(5), 437, 1-17. doi: $10.3390 / \mathrm{su} 8050437$.

Lupton, D. (2013). Introducing digital sociology. Sydney: University of Sydney.

Lupton, D. (2015). Digital sociology. New York, NY: Routledge.

Lyle, K. (2016). Shaping the future of sociology: The challenge of interdisciplinarity beyond the social sciences. Sociology, 51(6), 1169-1185. doi: 10.1177/0038038516653728.

Magu, S. (2015). Reconceptualizing cultural globalization: Connecting the "cultural global" and the "cultural local". Social Sciences, 4(3), 630-645. doi: 10.3390/socsci4030630.

Marres, N. (2017). Digital sociology: The reinvention of social research. Malden, MA: Polity (e-book version).

Nascimento, L. F. (2016). A sociologia digital: Um desafio para o século XXI [Digital sociology: A challenge for the 21st century]. Sociologias, 18(41), 216-241. doi: 10.1590/15174522-018004111.

Nnebedum, C. (2019). The value of integrating 21st century skills into the enterprise of teaching sociology. Academic Journal of Interdisciplinary Studies, 8(1), 37-44. doi: 10.2478/ajis-2019-0oo3.

Paiva, A. (2014). Pensamento sociológico. Uma introdução didática às teorias clássicas [Sociological thought. A didactic introduction to classical theories]. Lisboa: PACTOR: Edições de Ciências Sociais, Forenses e da Educação.

Rocher, G. (1989). Sociologia geral. A organização geral, 2 [General sociology. The general organisation, 2]. Lisboa: Editorial Presença.

Sallum Jr., B. (2005). O futuro das ciências sociais. A sociologia em questão [The future of social sciences. Sociology in question]. Sociologia - Problemas e Práticas, 48, 19-26.

Santos, A., \& Serpa, S. (2017). The importance of promoting digital literacy in higher education. International Journal of Social Science Studies, 5(6), 90-93. doi: 10.11114/ijsss.v5i6.2330.

Schroeder, R. (2010). The limits to transforming the environment and the limits to sociological knowledge. Sustainability, 2(8), 2483-2498. doi: 10.3390/su2082483.

Schwemmer, C., \& Wieczorek, O. (2019). The methodological divide of sociology: Evidence from two decades of journal publications. Sociology, oo3803851985314. doi: 10.1177/oo38038519853146.

Selwyn, N., \& Facer, K. (2014). The sociology of education and digital technology: Past, present and future. Oxford Review of Education, 40(4), 482-496. doi: 10.1080/03054985.2014.933005.

Serpa, S., \& Ferreira, C. M. (2018). Sociological problem and social problem: Contributions to a discussion. Sociology and Anthropology, 6(11), 840-844. doi: 10.13189/sa.2018.061104.

Serpa, S., Ferreira, C. M. and Santos, A. I. (2017). Fostering interdisciplinarity, Implications for social sciences. International Journal of Social Science Studies, 5(12), 44.

Serpa, S., \& Sá, M. J. (2019). Exploring sociology of education in the promotion of sustainability literacy in higher education. The Journal of Social Sciences Research, 5(1), 101-116. doi: 10.32861/jssr.51.101.116.

Silva, A. S., \& Pinto, J-. M. (1986). Uma visão global sobre as ciências sociais [A global view on social sciences]. In A. S. Silva, \& J. M. Pinto (Orgs.), Metodologia das ciências sociais [Methodology of social sciences] (pp. 927). Porto: Edições Afrontamento.

Suchacka, M., \& Horáková, N. (2019). Sociological barriers in the quality of production. Quality Production Improvement - QPI, 1(1), 1-8. doi: 10.2478/cqpi-2019-0oo1.

Van Koppen, C. S. A. (2017). Incorporating nature in environmental sociology: A critique of Bhaskar and Latour, and a proposal. Environmental Sociology, 3(3), 173-185. doi: 10.1080/23251042.2016.1272180.

Vásquez, J. M. (2020). La construcción social del futuro. Anotaciones desde la previsión humana y social [The social construction of the future. Notes from human and social welfare]. Cuadernos de Administración, 27, 226-263. 
Volkov, Y. G., Khunagov, R. D., Kumykov, A. M., Krotov, D. V., \& Magomedov, M. G. (2016). Sociology of the future: Humanization of sociological thought. International Journal of Environmental and Science Education, $11(16)$, 9586-9597.

Tutton, R. (2017). Wicked futures: Meaning, matter and the sociology of the future. The Sociological Review, 65(3), 478-492. Available at https://eprints.lancs.ac.uk/id/eprint/83992.

Witte, J. C. (2012). A ciência social digitalizada: Avanços, oportunidades e desafios [Digitized social science: Advances, opportunities and challenges]. Sociologias, 14(31), 52-92. doi: 10.1590/s1517-45222012000300004. 